\title{
Agromorphological Characterization of Introgression Lines Derived from Wild and Exotic Sorghum Germplasm to Climate Change Challenges
}

\author{
Ouindyam Colette Ouédraogo ${ }^{1,2^{*}}$, Nerbéwendé Sawadogo ${ }^{1^{*}}{ }^{\oplus}$, Eva Weltzien $^{3}$, Baloua Nebie $^{2}$, \\ Fred Rattunde 3 , Aboubacar Touré2, Ibrahima Sissoko², Mahamadou Sawadogo ${ }^{1}$ \\ ${ }^{1}$ Equipe Génétique et Amélioration des Plantes, Laboratoire Biosciences, Ecole Doctorale Sciences et Technologies, Université \\ Joseph Ki-Zerbo, Ouagadougou, Burkina Faso \\ ${ }^{2}$ International Crops Research Institute for the Semi-Arid Tropics (ICRISAT), Bamako, Mali \\ ${ }^{3}$ University of Wisconsin-Madison, Madison, WI, USA \\ Email: *coletteouaga@yahoo.fr, *nerbewende@yahoo.fr
}

How to cite this paper: Ouédraogo, O.C., Sawadogo, N., Weltzien, E., Nebie, B., Rattunde, F., Touré, A., Sissoko, I. and Sawadogo, M. (2021) Agromorphological Characterization of Introgression Lines Derived from Wild and Exotic Sorghum Germplasm to Climate Change Challenges. Agricultural Sciences, 12, 1129-1149.

https://doi.org/10.4236/as.2021.1210073

Received: September 10, 2021

Accepted: October 18, 2021

Published: October 21, 2021

Copyright $\odot 2021$ by author(s) and Scientific Research Publishing Inc. This work is licensed under the Creative Commons Attribution International License (CC BY 4.0).

http://creativecommons.org/licenses/by/4.0/ (c) (i) Open Access

\begin{abstract}
Sorghum (Sorghum bicolor (L.) Moench) is vitally important for food security in semi-arid West Africa. The introgression of wild- and high transpiration efficiency genotypes may contribute genes for abiotic stress tolerance or novel traits. Characterizing the introgressed lines can help researchers in the process of varietal improvement. The objectives of this study are (i) To learn if introgression of wild sorghum (CWR) and high transpiration efficiency (HTE) lines into a very early maturing (photoperiod insensitive) local land-race variety can create useful variation for grain yield in drought-prone Sahelian environments, (ii) To determine if grain yield advantages (and putative drought tolerance traits) obtained from introgression of CWR and HTE germplasm are expressed differently in moderately to highly moisture-limited environments, and (iii) To understand the relationship between putative drought tolerance traits. These populations were developed from crosses between the CSM63E (Jakumbe, a high grains quality variety) and two wild parents (accessions) and five high transpiration efficiency (TE) sorghum accessions. Phenotyping was conducted using an alpha lattice design with three replications in two environments for agronomic traits (grain yield and components), flowering time and physiological traits (stay-green, chlorophyll content and lodging). A total of 669 BC1F5 progenies were developed. Genetic variation for grain yield and putative drought tolerant traits were evaluated. Both populations derived from wild parents exhibited in Cinzana a grain yield $\left(>300 \mathrm{~g} / \mathrm{m}^{2}\right)$ greater than CSM63E $\left(245 \mathrm{~g} / \mathrm{m}^{2}\right)$. In Bema, more than
\end{abstract}


$75 \%$ of the progenies of all populations indicated a chlorophyll content at physiological maturity ( $>30$ SPAD) higher than CSM63E (20 SPAD) chlorophyll content. The estimated broad sense heritability was generally high $(\geq 0.50)$ for all traits. The results also showed a very significant interaction between genotype and environment for grain yield, flowering time, chlorophyll content, stay green and lodging. There was a strong correlation between stay green and chlorophyll content $(0.60)$ on the one hand and between stay green and lodging (0.48) on the other. This great variability could help improve the grain yield of sorghum for farmers in the Sahelian zone.

\section{Keywords}

Sorghum, Transpiration, Drought, Variability, Climate Change

\section{Introduction}

Sorghum [Sorghum bicolor (L.) Moench] is a staple crop the oldest cultivated in the arid and semi-arid tropics of West Africa [1] [2]. Sorghum is a main food crop of the daily diet of several million people in the semi-arid tropics of West Africa [3]. It is also used for animal feed, energy production and as housetops building material [4]. Despite its importance, sorghum improvement has not seen the same progress as maize, wheat and rice [5]. Indeed, most sorghum improvement work around the world has focused heavily on two of the five main races identified (guinea, bicolor, caudatum, durra and kafir), although the least studied races are vital for the majority. Smallholder farmers depend on sorghum for food security and resilience to climate change [6]. Contrary to the cotton-growing areas located in southern Mali, several new varieties-lines and hybrids are released [7] [8], only one improved variety, Jakumbè (CSM63E), is cultivated by farmers in the arid region of Mali [9].

In addition, in Africa, the average yield of sorghum is still very low. This low productivity of sorghum in West Africa is linked to climate variability, in particular the low and poor distribution of rainfall and the poor exploitation of sorghum genetic resources for improvement [10].

Thus, the development of improved sorghum varieties combining diverse traits and better drought tolerance with adaptation to local conditions could contribute to improving food security in drought prone areas, through higher yield and more stability. Sustainable gains in plant breeding rely on variation in the gene pool of crops. This involves exploring new genetic diversity as well as understanding the genetic and physiological basis of traits contributing to higher yields. Several studies have indeed reported the possibilities of improving many stress adaptation traits through the use of related wild and weed species [6] [11]. However, the transfer of useful traits from wild relatives and weeds into new varieties has only rarely been attempted in sorghum. 
Therefore, harnessing the genes of wild and weed sorghum is a promising approach to improve the genetic diversity of sorghum for adaptive traits and provide a basis for the selection of high performing, more resilient and widely adapted varieties. Thus, the objectives of this study are 1) To learn if introgression of wild sorghum (CWR) and high transpiration efficiency (HTE) lines into a very early maturing (photoperiod insensitive) local land-race variety can create useful variation for grain yield in drought-prone Sahelian environments, 2) To determine if grain yield advantages (and putative drought tolerance traits) obtained from introgression of CWR and HTE germplasm are expressed differently in moderately to highly moisture-limited environments, and 3) To understand the relationship between putative drought tolerance traits.

\section{Material and Methods}

\subsection{Plant Material}

Backcross nested association mapping (BCNAM) design was used to developed populations for this study using seven donor parents (two wild and five cultivated) and 1 recurrent parent. The recurrent parent CSM63E is an elite high yielding cultivar with grain quality, largely grown in the Sahelian zones and progressively in the Sudanian zone experiencing climate variability. The wild sorghums (BBISS-08 and BBISS-09) have the stay green character with also many tillers but have very small size seeds and other undesirable characteristics while the five cultivated donor parent were originated from Cameroon, Nigeria and Sudan (IS15428, IS16044, IS10876, IS16044 and IS3585) and differ from each other in their high transpiration efficiency (TE) and their racial and geographic diversity.

A total of 669 BC1F5 Backcross progenies from the wild sorghums BBISS-08 (BC08: $\mathrm{n}=85)$ and BBISS-09 (BC09: $\mathrm{n}=70)$ and from the cultivated sorghum IS15428 (BC15: $\mathrm{n}=108)$, IS16044 (BC16: $\mathrm{n}=107)$, IS10876 (BC10: $\mathrm{n}=99)$, IS16044 (BC161: $\mathrm{n}=98)$ and IS3585 (BC35: $\mathrm{n}=102)$ were developed through single seed descent method. These introgression progenies of a farmer-preferred sorghum landrace variety CSM63E were created by crossing each donor to the recurrent CSM63E and backcrossing the product to the recurrent parent, resulting in $\mathrm{BC} 1 \mathrm{~F} 1$ progenies with around $25 \%$ wild or cultivar donor and $75 \%$ cultivated-locally adapted backgrounds. Each BC1F1 seed was sowed in a single plot, selfed advance in BC1F2. One panicle of each BC1F2 derived progenies with maturities within the range of \pm 1 week of flowering of CSM 63E at the Cinzana station were retained for generation advance until BC1F4 through selfing and single plant selection. The bulked seed of 12 selfed individual BC1F4 plants was used for BC1F5 progeny evaluation. The population development method is shown in Figure 1.

Crossing and backcrossing took place at the Samanko experimental station in 2014. Population advancement was carried out at the Cinzana agronomic research station of the Institute of Rural Economy (IER) of Mali in 2015 and 2016. 


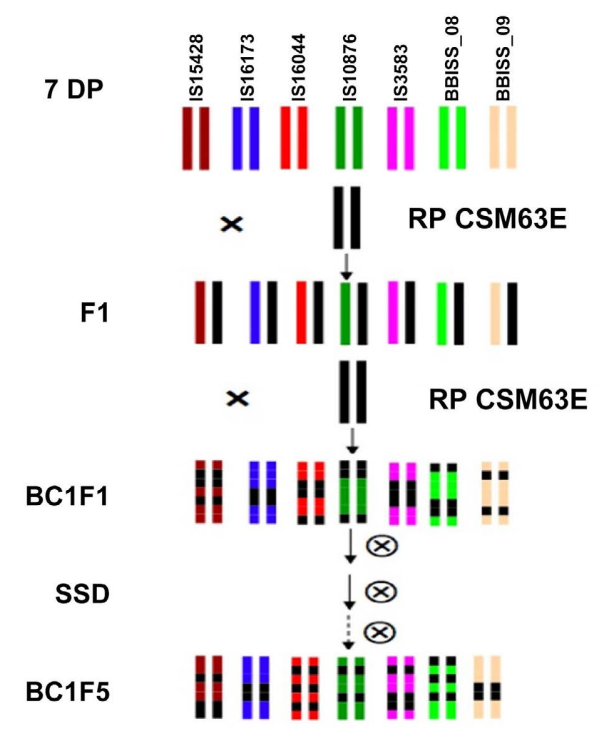

Figure 1. The design of backcross nested association mapping population of sorghum.

\subsection{Site and Experimental Design}

The agro-morphological characterization was carried out during the 2017 rainy season in two environments including Cinzana and the Bema. The Cinzana experimental station has a clay soil, richer in nutrients and more water-retaining, but heavier to work, especially when dry. It has an average temperature of $27.7^{\circ} \mathrm{C}$. While the station of Bema has a sandy-limous soil and an average temperature of $30^{\circ} \mathrm{C}$. Figure 2 showed the distribution of rainfall during this characterization period.

A set off 669 BC1F5 progenies including the donors, the recurrent parent CSM63E and a local control Seguifa were evaluated in two environments using a randomized incomplete block design with three replications. The randomization was done with the BMS software. Experimental plots consisted of a single 3-m row with $75-\mathrm{cm}$ distance between rows and $30 \mathrm{~cm}$ between hills within rows.

\subsection{Phenotypic Evaluation and Management}

The parental line, the CSM63E, the check and the 669 BC1F5 progenies were evaluated for grain yield and components, flowering time and physiological traits. For each environment the seeds of each of lines were sown in to each row after treatment with Apron Star. Three weeks after emergence, the seedlings were thinned to 2 plants per hill. Mineral fertilization was done according to the required standards, DAP was applied before ridging at a rate of $100 \mathrm{~kg} / \mathrm{ha}$ and 50 $\mathrm{kg} / \mathrm{ha}$ of urea $(46 \% \mathrm{~N})$ after 45 days after sowing. Two weedings were done if need and the plot was protected from birds to minimize their impact on the plants. Phenotyping was carried out for agronomic traits of grain yield, flowering time and for physiological traits such as chlorophyll content (SPAD), visual score of green leaf area (STG) and lodging (Ver) were also estimated. A total of eleven (11) quantitative and qualitative traits were used for agro-morphological 


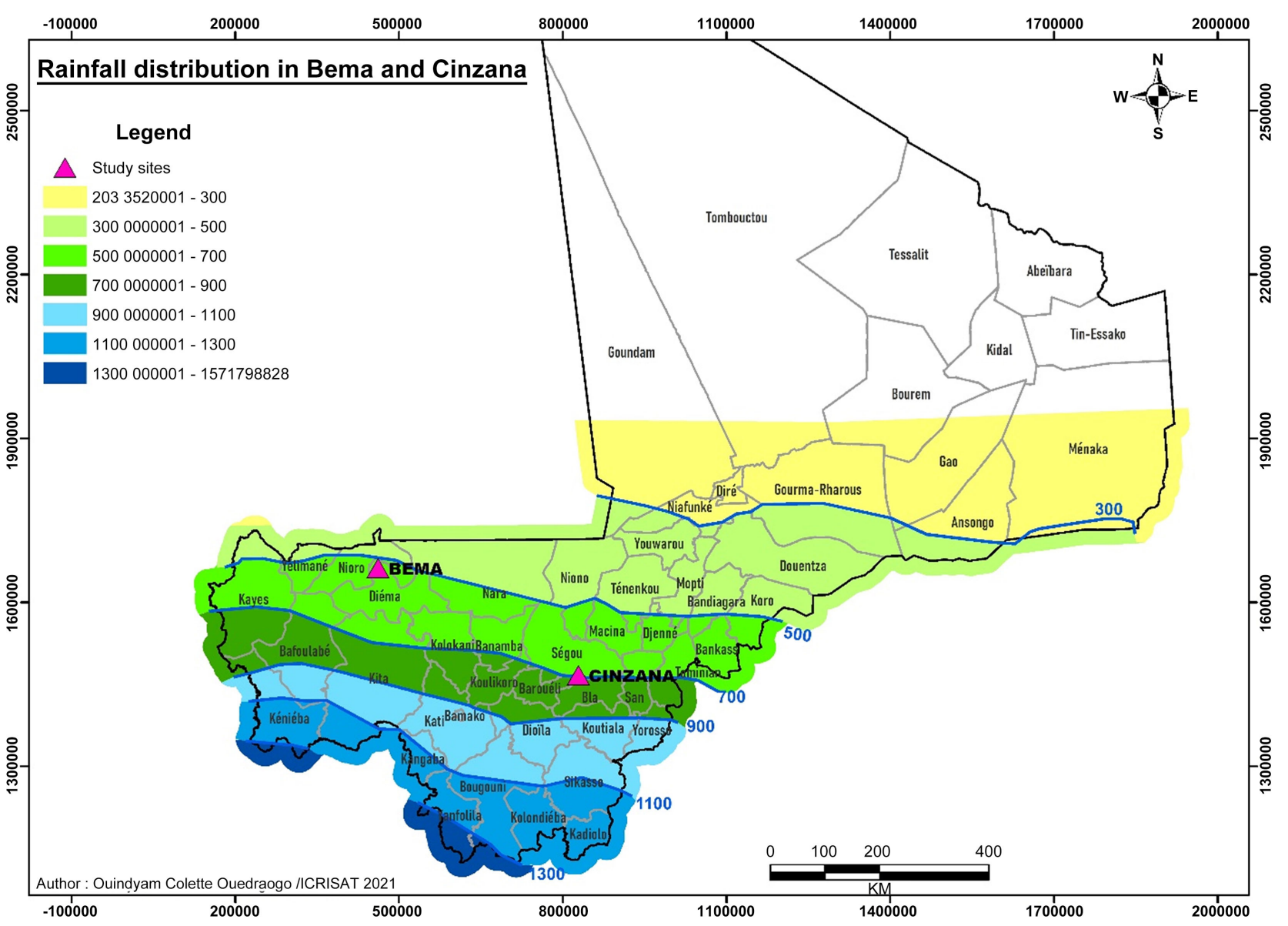

Figure 2. Distribution of rainfall in the different locations.

evaluation. The grain yield and the 50\% flowering time were observed on the whole plot, the other traits were measured on three (3) plants randomly selected per line. Plant height was measured in centimeters from the soil to the tip of the panicle. Panicle length was measured in centimeters from the bottom to the tip of the panicle. The weight of 100 grains (Pcg) was recorded and the vitreosity (Vit) of the grains was noted according to a scale of 1 to 10. A Minolta SPAD-502 meter was used to measure the relative chlorophyll content from five tagged plants in a plot. These measurements were taken 30 days after sowing, at flowering, and at plant maturity on the flag leaf of the plants [12]. Three measurements were taken on the flag leaf and the average of these measurements was taken. Averages of these measurements in each plot were used for analysis. In addition, green leaf area was visually scored at maturity on a scale of 1 to 5 , where $1=$ completely dead plant and $5=$ completely green plant. The score was based on the number of green leaves on the plant, leaf size, and dry areas on the leaf at maturity. Lodging was scored based on the ability of the plants to remain up on the plot at maturity, the total number of standing plants in the plot was counted. The lodging score scale was 0 to $100(100=$ all plants in the plot are completely upright and $0=$ all plants in the plot are completely fallen). Flower- 
ing data were recorded by counting the number of days from sowing until $50 \%$ of the plants in each plot had flowered.

\subsection{Phenotypic Data Analysis}

Single environment analysis was done for each trait. The BMS (Breeding View) software was used to obtain the best linear unbiased estimate (BLUES) and the best linear unbiased prediction estimate (BLUP). Two models were used to run the analysis to obtain the BLUEs and BLUPs. In the first model, the genotype was taken as a random factor and the environment as a fixed factor and in the second model, the genotype was considered as fixed. The following formulas were used: Model:

$$
Y_{i j k}=\mu+G_{i}+R_{j}+B_{k}+B(R)_{l}+E_{i j k}
$$

where $Y_{i j k}$ is the observed value; $\mu$ is the population mean; $G_{i}$ is the effect due to the $i$-th genotype tested; $R_{j}$ is the effect due to the $j$-th replicate; $B_{k}$ is the effect due to the $k$-th block; $B(R)=$ interaction effect of the block in the replicate; $E_{i j k}$ is the effect due to the random error.

The genotype factor that was taken as random was used to calculate the predicted values and standard error for each genotype. $R$ software was used for analysis of correlation, variance (ANOVA) and graphs.

The grain yield was calculated as follows:

$$
\mathrm{GY}\left(\mathrm{g} / \mathrm{m}^{2}\right)=\frac{\mathrm{PGr}}{0.75(3+0.6)}
$$

where $0.75=$ line spacing; $3=$ length of the sowing row; $0.6=2$ borders corresponding to the inter-hill, GY is the grain yield and PGr is the grain weight.

Coefficients of genotypic variation (CGV) were calculated according to the method proposed by [13] to allow comparisons of genetic variability of all traits between trials.

$$
\operatorname{CVG}(\%)=\frac{\sqrt{\sigma_{g}^{2}}}{\mu} \times 100 \text { and } \operatorname{CVP}(\%)=\frac{\sqrt{\sigma_{g}^{2}}}{\mu} \times 100
$$

where $\sigma_{g}^{2}$ is the genotypic variance component, and $\mu$ is the overall trial mean.

To obtain the average variance of a difference $(a V D)$ between genotypes, the square root of the standard error of difference (SEd) was estimated and normalized by dividing it by the grand mean of the trial. The strict heritability $h^{2}$ was calculated based on the formula of Cullis et al. [14].

$$
h^{2}=1-\frac{a V D}{2 V g}
$$

with $V g=$ genetic variance and $a V D=$ average variance of a difference.

Combined analysis was done for the two environments. The combined analysis was done by fixing the environment and randomizing the genotype. The model used is as follows: 


$$
Y_{i j k}=\mu+G_{i}+E_{j}+G E_{i j}+E R_{j k}+E R B_{j k l}+e_{i j k l}
$$

where $Y_{i j}$ is the adjusted mean of the th genotype in the $j$ th environment, $\mu$ is the grand mean, $G_{i}$ is the effect of genotype $i, E_{j}$ is the effect of level $j$ of the environment, $G E_{i j}$ is the effect of the interaction between genotype $i$ and level $j$ of the environment, $E R_{j k}$ is the effect of the interaction between level $j$ of the environment and repetition $k, E R B_{j k l}$ is the effect of the interaction of the blocks in the repetition and in the level of the environment and $e_{i j k l}$ is the residual.

The broad heritability $\left(H^{2}\right)$ was calculated using the method described by Piepho and Möhring [15]:

$$
H^{2}=\frac{V g}{V g+\left(\frac{V g e}{n E}\right)+\left(\frac{V e}{n E} * n R\right)}
$$

where: $V g=$ genotypic variance, $n E=$ number of environments, $V g e=$ variance of the genotype-environment interaction, $n R=$ number of repetitions and $V e=$ variance error.

The genetic correlation $\left(r_{g}\right)$ between the different putative drought tolerance traits was calculated as follows:

$$
r_{g}=\frac{\operatorname{Cov}(\text { caractere } 1 ; \text { caractere } 2)}{[\sigma(\text { caractere } 1) \times \sigma(\text { caractere } 2)]}
$$

where: Cov (trait1; trait2) is the covariance of the genotype means of trait1 compared to trait $2 ; \sigma$ (trait 1$)$ and $\sigma$ (trait2) are the genotypic standard deviation of trait1 and trait 2 respectively.

\section{Results}

\subsection{Progenies Performance for Grain Yield}

Figure 3 showed a considerable difference in grain yield among progenies within and between the seven populations BC10, BC15, BC16, BC161, BC08, BC09 et BC35. The Cinzana environment showed the best performance in grain yield compared to Bema. Grain yields at the Bema were ranged from 30 to $240 \mathrm{~g} / \mathrm{m}^{2}$, whereas at the Cinzana, grain yield was ranged from 80 to $500 \mathrm{~g} / \mathrm{m}^{2}$. The best grain yield was obtained in the BC10 population $\left(240 \mathrm{~g} / \mathrm{m}^{2}\right)$ at Bema, while the BC15 population $\left(500 \mathrm{~g} / \mathrm{m}^{2}\right)$ had the highest grain yield at Cinzana compared to the recurrent parent CSM63E. Thus, at Bema, 50\% of the progenies of populations had a higher grain yield $\left(>100 \mathrm{~g} / \mathrm{m}^{2}\right)$ than CSM63E $\left(39 \mathrm{~g} / \mathrm{m}^{2}\right)$, while at Cinzana only the progenies of two populations (BC09 and BC15) had a higher grain yield $\left(>300 \mathrm{~g} / \mathrm{m}^{2}\right)$ than CSM63E $\left(>245 \mathrm{~g} / \mathrm{m}^{2}\right)$. The progenies of the BC16 population gave the lowest grain yields at Cinzana compared to the recurrent parent.

\subsection{Progenies Performance for Early Flowering}

Figure 4 showed the variability of flowering time within progenies at the two 


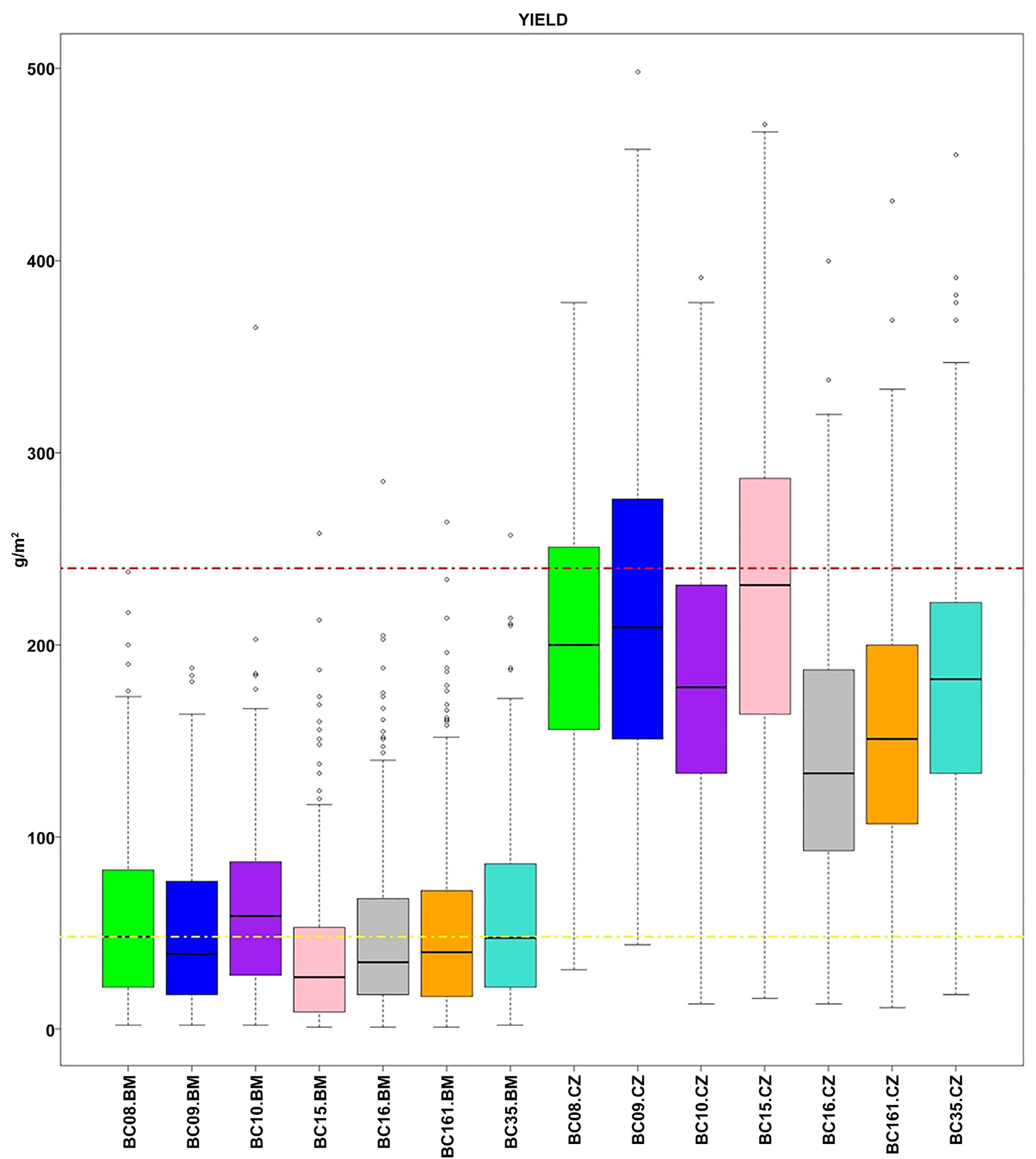

Figure 3. Grain yield of seven populations in two environments Bema (BE) and Cinzana (CZ) compared to the yield of CSM63E. Red and yellow dotted lines: respective yield of CSM63E in Cinzana and Bema. BC08 and BC09 are the progenies from the two wild relatives. $\mathrm{BC} 10, \mathrm{BC} 15, \mathrm{BC} 16, \mathrm{BC} 161$ and $\mathrm{BC} 35$ are the progenies from the high transpiration efficiency parents.

environments. At the Bema, flowering time ranged from 51 to 95 days, while at Cinzana it ranged from 54 to 84 days. With the exception of progenies from the cross between CSM63E and the wild parent BC08 (Population BC08), most of 


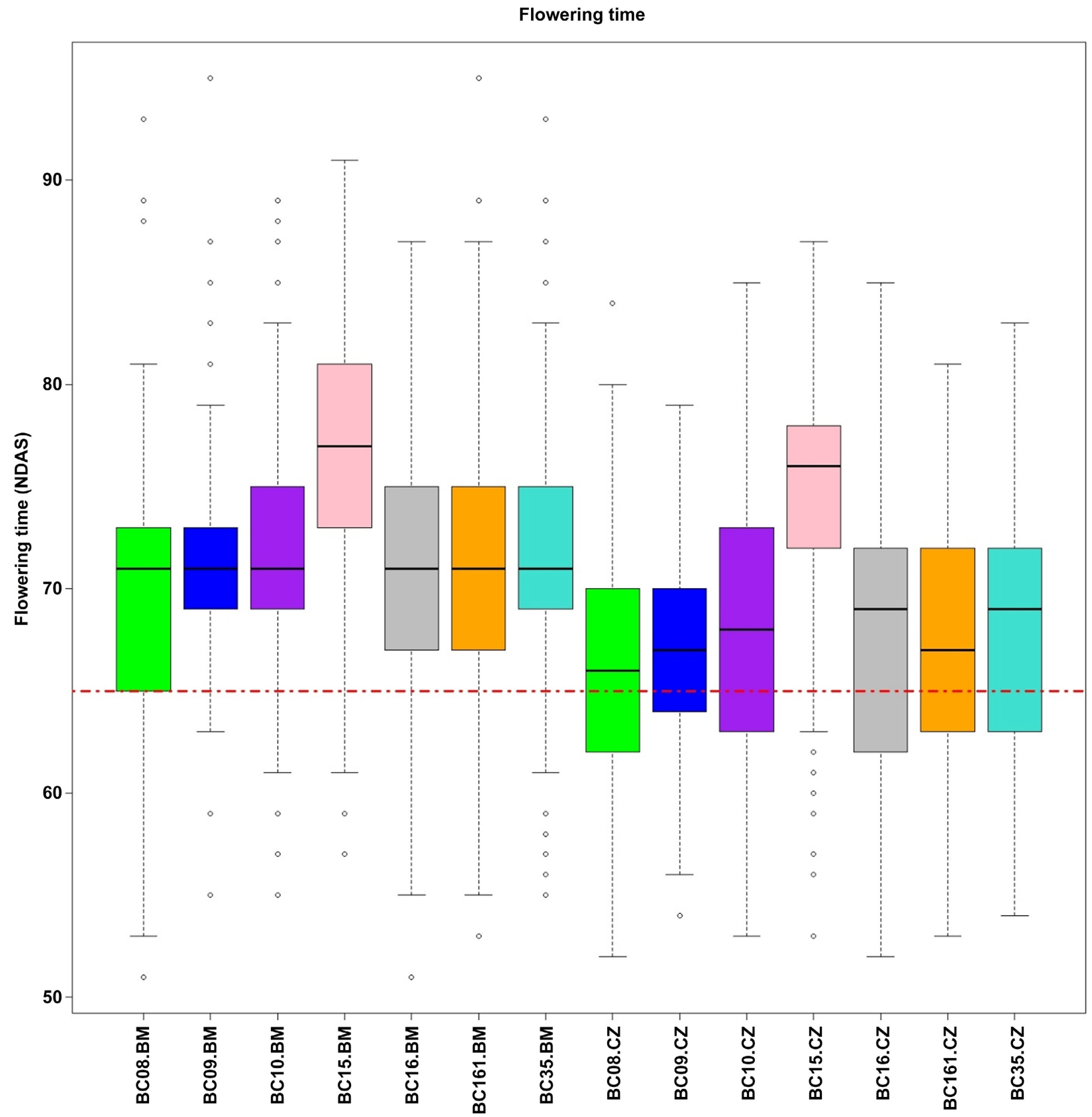

Figure 4. Flowering date of seven populations in two environments Bema (BE) and Cinzana (CZ) compared to that of CSM63E. Red dotted lines: respective flowering time of CSM63E in Cinzana and Bema. BC08 and BC09 are the progenies from the two wild relatives. $\mathrm{BC} 10, \mathrm{BC} 15, \mathrm{BC} 16, \mathrm{BC} 161$ and $\mathrm{BC} 35$ are the progenies from the high transpiration efficiency parents.

the progenies were late maturing compared to CSM63E which was 65 days in both environments. The earliest progeny from the $\mathrm{BC} 08$ population reached 50\% flowering 10 days before the flowering period of CSM63E. Progeny from the $\mathrm{BC} 15$ population tended to have the same flowering dates regardless of site.

\subsection{Progenies Performance for Chlorophyll Content}

The BC1F5 progenies exhibited a large variability in terms of chlorophyll con- 
tent in both environments by the large variation among progenies which was also observed within each population shown by Figure 5. At Bema, most of the progenies of all populations expressed a chlorophyll content ( $>35$ SPAD) higher than CSM63E (22 SPAD). At Cinzana, the chlorophyll content of CSM63E was

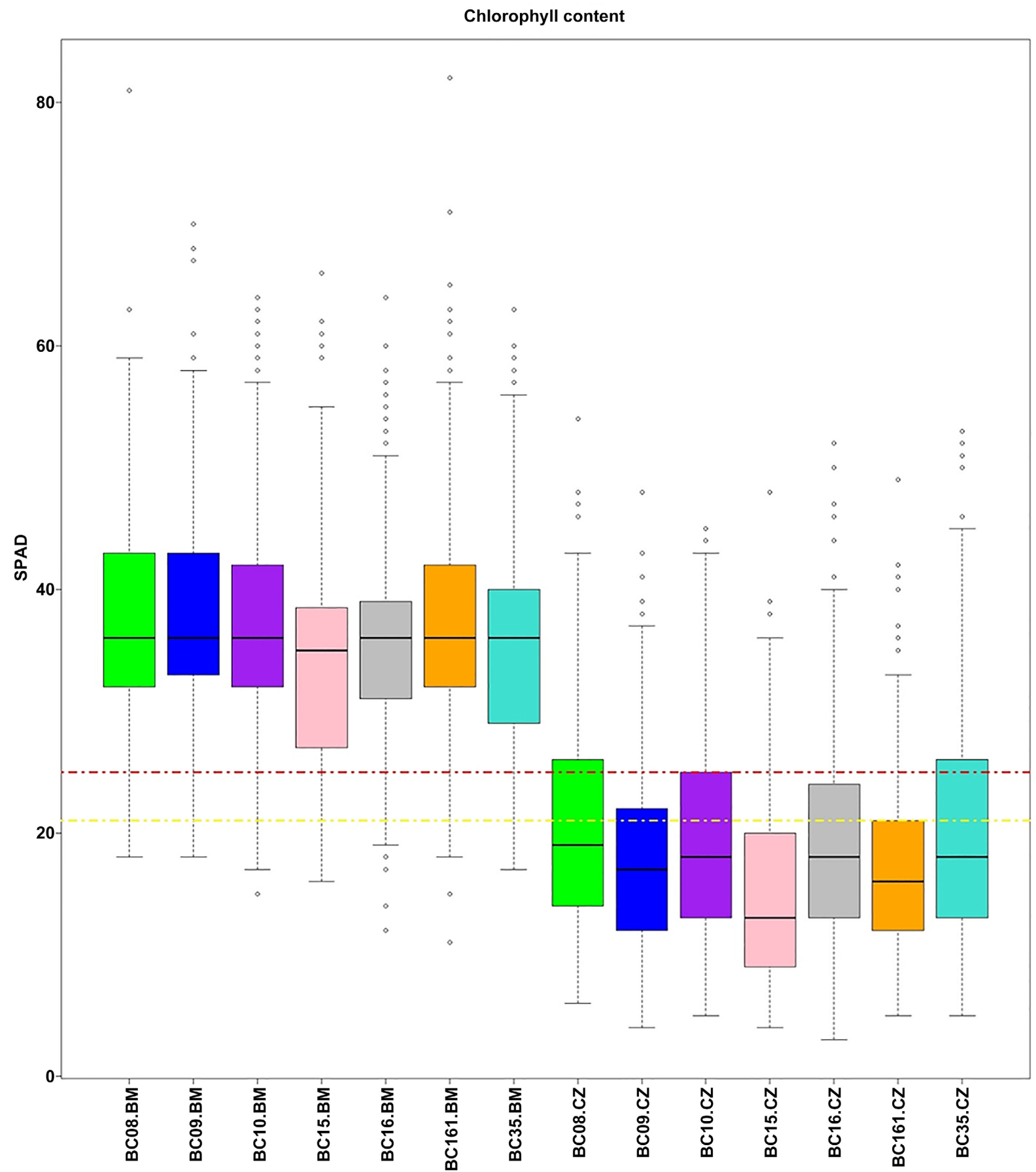

Figure 5. Chlorophyll content at maturity of seven populations in two environments Bema (BE) and Cinzana (CZ) compared to that of CSM63E. Red and yellow dotted lines: respective chlorophyll content of CSM63E in Cinzana and Bema. $\mathrm{BC} 08$ and $\mathrm{BC} 09$ are the progenies from the two wild parents. $\mathrm{BC} 10, \mathrm{BC} 15, \mathrm{BC} 16, \mathrm{BC} 161$ and $\mathrm{BC} 35$ are the progenies from the high transpiration efficiency parents. 
superior to more than $75 \%$ of the progenies. The chlorophyll content of the seven populations at the Bema is higher than those of the populations at the Cinzana site (Figure 5).

\subsection{Estimates of Genotypic Variances in Populations}

Significant phenotypic variation among progenies was observed for morphological, physiological and grain yield traits in each environment shown by the range between the minimum and maximum of the traits. The differences were similar in both environments. Except the average grain yield at Bema, the average value of all traits was lower than the value of CSM63E (Table 1). The overall genotypic coefficients of variation (GCV_G) for the traits analyzed ranged from $6.8 \%$ to $28.4 \%$ at Cinzana and $5.1 \%$ to $65.3 \%$ at Bema. The genotypic coefficients of

Table 1. Estimates of genotypic variances, ranges and heritabilities in the two environments.

\begin{tabular}{|c|c|c|c|c|c|c|c|c|c|}
\hline Environment & Traits & Mean & Minimum & Maximum & CSM63E & GCV_G & GCV_CWR & GCV_HTE & Heritability \\
\hline \multirow{11}{*}{ BEMA } & FLWT & 72.3 & 51 & 95 & 67 & 5.1 & 20.5 & 47.5 & 0.9 \\
\hline & HPL & 264.1 & 179.1 & 334.1 & 308 & 21.4 & 61.9 & 56.3 & 0.8 \\
\hline & LonPa & 29.5 & 18.7 & 39.8 & 37 & 21.3 & 53.1 & 66.1 & 0.9 \\
\hline & SPADI & 34.7 & 31.9 & 38.5 & 34 & 6.4 & 13.1 & 20.3 & 0.3 \\
\hline & SPADII & 44.9 & 36.5 & 54.8 & 53 & 6.6 & 14.1 & 34 & 0.7 \\
\hline & SPADIII & 38.1 & 18 & 81 & 22 & 10.3 & 10 & 10.3 & 0.7 \\
\hline & Ver & 90.1 & 82.6 & 94.1 & 100 & 15.1 & 4.5 & 20.5 & 0.3 \\
\hline & STG & 3.8 & 1 & 3.9 & 2 & 23.5 & 29 & 12.3 & 0.5 \\
\hline & GY & 50 & 30 & 240 & 39 & 65.3 & 45.3 & 35.5 & 0.7 \\
\hline & PCG & 1.9 & 1.7 & 2.1 & 2 & 13.1 & 7 & 29 & 0.8 \\
\hline & Vit & 4.5 & 1 & 8.8 & 3.2 & 50.9 & 59 & 61.8 & 0.9 \\
\hline \multirow{11}{*}{ CINZANA } & FLWT & 68.8 & 54 & 84 & 67 & 6.8 & 17.8 & 27 & 0.6 \\
\hline & HPL & 281.7 & 167.9 & 356.1 & 310 & 12.3 & 25.3 & 16.3 & 0.6 \\
\hline & LonPa & 30.7 & 19.2 & 42.9 & 34 & 11.9 & 32.4 & 26.8 & 0.7 \\
\hline & SPADI & 37.4 & 31.3 & 46.3 & 43 & 7.2 & 4.4 & 13.6 & 0.3 \\
\hline & SPADII & 50.7 & 42.5 & 72.7 & 55 & 7.6 & 4.9 & 15.1 & 0.1 \\
\hline & SPADIII & 19.7 & 4 & 54 & 22 & 28.4 & 26.4 & 17.5 & 0.3 \\
\hline & Ver & 72.1 & 52.2 & 82.1 & 100 & 21.4 & 32.5 & 31.1 & 0.3 \\
\hline & STG & 2.2 & 1.6 & 2.85 & 2 & 22.5 & 11.1 & 21.1 & 0.6 \\
\hline & GY & 210 & 80 & 500 & 245 & 25.6 & 23 & 31.5 & 0.5 \\
\hline & PCG & 2.1 & 2 & 2.6 & 2 & 11.8 & 28.7 & 114.1 & 0.6 \\
\hline & Vit & 4.2 & 1.2 & 8.8 & 7 & 27.4 & 33.9 & 54.7 & 0.5 \\
\hline
\end{tabular}

FLWT: Flowering time; HPL: Plant height; LonPa: Length of the panicle; SPADI: Chlorophyll content 30 days after sowing; SPADII: Chlorophyll content at flowering; SPADIII: Chlorophyll content at maturity; Ver: Lodging; STG: Stay green; GY: Grain yield; PCG: One hundred grain weight; vit: Vitreosity; CVG_G: overall genotypic coefficient of variance; CVG_CWR: coefficient of genotypic variance of progenies from wild parents; CVG_HTE: genotypic coefficient of variance of progenies from parents with high transpiration efficiency. 
variation of CWR progenies (GCV_CWR) and HTE progenies (GCV_HTE) are generally higher than the overall genotypic coefficient for all traits. The CWR-GCVs for the traits stay green and grain yield at Bema are higher compared to the HTE-GCVs at Cinzana. These coefficients of variation are higher for the characters chlorophyll content at maturity, stay green, lodging, vitreosity and grain yield. They are medium for the traits plant height, panicle length and hundred kernel weight and low for the traits flowering date and chlorophyll content at flowering. Heritability is high for all traits except chlorophyll content and lodging.

\subsection{Genotype, Environment and Genotype × Environment Effects on Grain Yield and Its Components}

Table 2 indicates the results of the combined analysis of variance of grain yield and its components. Analyzes showed a significant effect of genotype on the expression of agronomic traits panicle length, plant height, and grain yield in both environments. However, it was not significant $(p>00.5)$ on the chlorophyll content, the one hundred grain weight and the vitreousness at Cinzana. Regarding the effect of the interaction between the genotype and the environment, it was highly significant for grain yield. The genotype $\times$ environment interaction also had a significant effect on grain weight $(\mathrm{p}<0.005)$ and vitreousness $(\mathrm{p}<0.001)$.

Table 2. Analysis of variance: individual and combined analyzes of the two environments Bema and Cinzana for agronomic traits and chlorophyll content.

\begin{tabular}{|c|c|c|c|c|c|}
\hline & & Individual & & Combined & \\
\hline Traits & Variance & $S_{g}^{2}$ & $S_{g}^{2}$ & $S_{e}^{2}$ & $S_{g x e}^{2}$ \\
\hline \multirow[b]{2}{*}{ HPL } & $\mathrm{BM}$ & $687^{* * *}$ & \multirow[b]{2}{*}{$1765.8^{*}$} & \multirow[b]{2}{*}{$94,048 \mathrm{~ns}$} & \multirow[b]{2}{*}{$56.5 \mathrm{~ns}$} \\
\hline & $\mathrm{CZ}$ & $1135^{\star * *}$ & & & \\
\hline \multirow[b]{2}{*}{ LonPa } & $\mathrm{BM}$ & $22^{* * *}$ & \multirow[b]{2}{*}{$50.1^{\star}$} & \multirow[b]{2}{*}{$672 \mathrm{~ns}$} & \multirow[b]{2}{*}{$0.3 \mathrm{~ns}$} \\
\hline & $\mathrm{CZ}$ & $27^{\star *}$ & & & \\
\hline \multirow[b]{2}{*}{ SPADI } & $\mathrm{BM}$ & $222.9^{* * *}$ & \multirow[b]{2}{*}{$8.9^{*}$} & \multirow[b]{2}{*}{$2358 \mathrm{~ns}$} & \multirow[b]{2}{*}{$1.9 \mathrm{~ns}$} \\
\hline & $\mathrm{CZ}$ & $269 \mathrm{~ns}$ & & & \\
\hline \multirow[b]{2}{*}{ SPADII } & $\mathrm{BM}$ & $296.7^{\star * *}$ & \multirow[b]{2}{*}{$28.2 \mathrm{~ns}$} & \multirow[b]{2}{*}{$11039 n s$} & \multirow[b]{2}{*}{$2.5 \mathrm{~ns}$} \\
\hline & $\mathrm{CZ}$ & $360 \mathrm{~ns}$ & & & \\
\hline \multirow{2}{*}{ PCG } & $\mathrm{BM}$ & $24.2^{\star * *}$ & \multirow{2}{*}{$0.1 \mathrm{~ns}$} & \multirow{2}{*}{$0.8 \mathrm{~ns}$} & \multirow{2}{*}{$0.1^{*}$} \\
\hline & $\mathrm{CZ}$ & $23.6 \mathrm{~ns}$ & & & \\
\hline \multirow[b]{2}{*}{ Vit } & $\mathrm{BM}$ & $229^{* *}$ & \multirow[b]{2}{*}{$2.4^{*}$} & \multirow[b]{2}{*}{$71 \mathrm{~ns}$} & \multirow[b]{2}{*}{$2.4^{* *}$} \\
\hline & $\mathrm{CZ}$ & $109.6 \mathrm{~ns}$ & & & \\
\hline \multirow[b]{2}{*}{ GY } & $\mathrm{BM}$ & $3265.4^{\star * *}$ & \multirow[b]{2}{*}{$2182.6^{* * *}$} & \multirow[b]{2}{*}{$57,777^{\star * *}$} & \multirow[b]{2}{*}{$1469^{* * *}$} \\
\hline & $\mathrm{CZ}$ & $5373.6^{* * *}$ & & & \\
\hline
\end{tabular}

BM: Bema; CZ: Cinzana; HPL: Plant height; LonPa: Length of the panicle; SPADI: Chlorophyll content 30 days after sowing; SPADII: Chlorophyll content at flowering; PCG: One hundred grain weight; vit: Vitrosity; GY: Grain yield G: Genotype; E: Environment; GXE: Genotype and environment interaction. ${ }^{*},{ }^{* *}{ }^{* * *}$ Significant difference for the probability at $0.1,0.01$ and 0.001 respectively. Ns $=$ not significant. 


\subsection{Analysis of Putative Drought Tolerance Traits}

The analysis results of putative drought tolerance traits for the parental lines and the BC1F5 was presented in Table 3. Most of the traits showed a heritability between 0.2 and 0.8 . The score of the stay green trait for the donor parents was higher than that of the recurrent parent CSM63E in both environments, with an average of 3.2 for Bema and 2.5 for Cinzana, while the average score for the recurrent parent was 2. The average score of the stay green trait for the BC1F5 was 3.6 and 2.2 respectively for Bema and Cinzana with a range of 1 to 5. A highly significant difference was observed between the BC1F5 progenies for this trait in both environments. For lodging, CSM63E showed a value of $100 \%$ compared to donors with an average value of $70 \%$ and $78.5 \%$ respectively in Bema and Cinzana. The BC1F5 showed a significant difference between the progenies for the lodging trait in the two environments with an average value of $85.7 \%$ and $72.1 \%$ respectively in Bema and Cinzana with a variation between $0 \%$ and $100 \%$. Plants of the $\mathrm{BC} 1 \mathrm{~F} 4$ progeny tended to stay upright and green in the Bema zone compared to Cinzana environment.

The recurrent parent CSM63E exhibited a shorter flowering time (65 and 67 days respectively in Bema and Cinzana) compared to the donor parents (70 and 74 days respectively in Bema and Cinzana). The parental lines differed considerably in terms of the number of flowering days. Highly significant differences were observed between BC1F5 for flowering time and chlorophyll content at maturity. The BC1F5 progenies showed a mean value of 70 and 68 days with a variation of 51 to 95 days and 52 to 87 days respectively at Bema and Cinzana. In both environments, CSM63E flowered on average five days before the donor parents. Regarding the chlorophyll content at maturity, an interval of variation of 5 - 81 SPAD and 10 - 34 SPAD was observed among the BC1F4 progenies in

Table 3. Traits Mean of the recurrent parent (CSM63E), the donor parents and, variation (minimum-maximum), mean square and broad heritability $\left(h^{2}\right)$ of the $\mathrm{BC} 1 \mathrm{~F} 4$ progenies in two environments (Bema and Cinzana).

\begin{tabular}{cccccccc}
\hline \multirow{5}{*}{ BEMA } & Traits & $\begin{array}{c}\text { Mean } \\
\text { CSM63E }\end{array}$ & $\begin{array}{c}\text { Mean } \\
\text { Donors }\end{array}$ & $\begin{array}{c}\text { Mean } \\
\text { BC1F5 }\end{array}$ & Variation & Mean square & $H^{2}$ \\
& FLWT (j) & 67 & 70 & 70.7 & $51-95$ & $170.5^{* * *}$ & 0.6 \\
& STG (1-5) & 2 & 3.2 & 3.6 & $1-5$ & $3.67^{*}$ & 0.5 \\
& Ver (\%) & 100 & 71 & 85.7 & $0-100$ & $1230.2^{*}$ & 0.2 \\
& SPADIII & 21 & 28 & 30.2 & $5-81$ & $192.3^{*}$ & 0.3 \\
\hline \multirow{5}{*}{ CINZANA } & FLWT (j) & 67 & 74 & 68.7 & $52-87$ & $115.7^{* * *}$ & 0.8 \\
& STG (1- 5) & 2 & 2.5 & 2.2 & $1-5$ & $1.42^{*}$ & 0.3 \\
& Ver (\%) & 100 & 78.5 & 72.1 & $0-100$ & $1499.2^{*}$ & 0.2 \\
& SPADIII & 22.3 & 14.6 & 18.5 & $10-34$ & $115.6^{* * *}$ & 0.3 \\
\hline
\end{tabular}

FLWT: Flowering time; SPADIII: Chlorophyll content at maturity; Ver: Lodging; STG: Stay green; ${ }^{*} * * *$ Significant difference for the probability levels at 0.1 and 0.001 respectively. 
both with an average value of 30.2 SPAD and 18.5 SPAD respectively in Bema and Cinzana.

The broad sense of heritability of the different putative drought tolerance traits ranged from 0.2 to 0.8 . Heritability was high for the flowering time trait in both environments (Table 3 ).

Regarding genotype $\times$ environment interaction, it revealed significant differences among the $\mathrm{BC} 1 \mathrm{~F} 5$ progenies for each putative drought tolerance trait across the two environments. Estimates for the genotypic variance $\sigma_{g}^{2}$ indicated significant effects for all traits evaluated. The estimated broad heritability was higher $(>0.5)$ (Table 4$)$.

\subsection{Correlations between Traits}

The estimated phenotypic correlation coefficients for the different traits were given in Table 5. A significant but weak correlation between the flowering time and stay green traits, the flowering time and lodging and finally between the flowering time and chlorophyll content at 30 days after sowing was observed. Stay green was strongly correlated with lodging and stay green was also correlated with chlorophyll content at maturity. Lodging showed a very significant

Table 4. Genotypic variance $\left(\sigma_{g}^{2}\right)$, standard error $(\mathrm{SE})$, genotype $\times$ environment variance $\left(\sigma_{g x e}^{2}\right)$ and broad sense of heritability $\left(h^{2}\right)$ of the BC1F5 progenies for the flowering time (FLWT), the stay green (STG), the lodging (Ver) and chlorophyll content.

\begin{tabular}{cccccc}
\hline Traits & $\sigma_{g}^{2}$ & SE & $\sigma_{g x e}^{2}$ & SE & $H^{2}$ \\
\hline FLWT & $27.5^{*}$ & 1.6 & $6^{*}$ & 0 & 0.6 \\
STG & $0.1^{\star *}$ & 0. & $1.1^{\star}$ & 0.1 & 0.4 \\
Ver & $78.4^{\star * *}$ & 15.1 & $113.6^{* * *}$ & 28 & 06 \\
SPADIII & $4.9^{* * *}$ & 1.4 & $147.3^{* * *}$ & 37 & 0.5 \\
\hline
\end{tabular}

FLWT: Flowering time; SPADIII: Chlorophyll content at maturity; Ver: Lodging; STG: Stay green; ${ }^{\star},{ }^{* *},{ }^{* *}$ Significant differences at $0.1,0.01$ and 0.001 respectively. Ns $=$ not significant.

Table 5. Correlations between traits

\begin{tabular}{cccccccc}
\hline Traits & FLWT & STG & Ver & SPADI & SPADII & SPADIII & GY \\
\hline FLWT & 1 & & & & & & \\
STG & $0.1^{\star * *}$ & 1 & & & & & \\
Ver & $0.1^{* * *}$ & $0.5^{* * *}$ & 1 & & & & \\
SPADI & $0.1^{* * *}$ & $0.1^{\star * *}$ & $0.2 \mathrm{Ns}$ & 1 & & & \\
SPADII & $0.1 \mathrm{Ns}$ & $0.1^{\star * *}$ & $0.2 \mathrm{Ns}$ & $0.3^{* * *}$ & 1 & & \\
SPADIII & $0.1 \mathrm{Ns}$ & $0.6^{* * *}$ & $0.3^{* * *}$ & $0.1 \mathrm{Ns}$ & $0.1^{\star * *}$ & 1 & \\
GY & $-0.1 \mathrm{Ns}$ & $-0.2 \mathrm{Ns}$ & $-0.8^{* * *}$ & $0.3 \mathrm{Ns}$ & $0.1 \mathrm{Ns}$ & $-0.7^{* * *}$ & 1 \\
\hline
\end{tabular}

FLWT: Flowering time; SPADI: Chlorophyll content 30 days after sowing; SPADII: Chlorophyll content at flowering; SPADIII: Chlorophyll content at maturity; Ver: Lodging; STG: Stay green; GY: Grain yield; *** Significant differences at 0.001 . Ns $=$ not significant. 
correlation with the content of chlorophyll at maturity $\left(r=0.3^{* * *}\right)$. The grain yield showed a significant correlation with lodging and the grain yield was also correlated with the content of chlorophyll at maturity.

\section{Discussion}

The progenies of the different populations expressed superior performance to the donor parents and to the recurrent parent CSM63E, especially in terms of grain yield, chlorophyll content and flowering time in both types of environments, showing the positive effect of the introgression. In addition, the superiority of the BC09 population over other populations and over the recurrent parent CSM63E could be explained by the fact that the wild relatives were generally found in a wide range of environments providing a source of genotypes adapted to new or changing environments in agricultural production areas [16]. Wild relatives of crops are a source of genes that have enabled significant advances in crop productivity [17] [18].

All populations provided a varied range of flowering time for populations in both types of environments. This could suggest that the material developed can be used for different agroecological zones. The variation in the flowering date was indeed a key feature in the adaptation of cultivated plant populations to environmental conditions [19]. The progenies developed showed adaptation to Cinzana as well to Bema. Quinby [20] showed that the flowering date has major impacts on crop performance during periods of terminal drought. Hanmier [21] indicated that a difference of 5 days between two varieties can express very large differences in grain yield.

The significant level of genetic variation in grain yield, flowering period, chlorophyll content and stay green observed in the seven populations could be due on the one hand to the possibilities of improving the genetic material of sorghum through the use of both high transpiration efficiency sorghum cultivars and wild sorghum and the other hand due to the method of development of the populations. Thus, differences in mean and frequency were noted among the best performing genotypes in progenies derived from the cross between the recurrent parent (CSM63E) and the wild parents and in one of the BC15 populations (cross between CSM63E and IS15428) regarding the grain yield, flowering period, chlorophyll content and stay green traits. Exploitation of wild species and cultivars with high transpiration efficiency could therefore contribute to increasing the diversity of genetic material. According to Gill et al. [22], wild plants have been exposed to extreme climatic conditions and have evolved in terms of adaptive traits and therefore constitute an important source of new traits. Bramel-Cox and Cox [6] also reported the possibility of increasing sorghum yields through the transfer of genes from wild races of sorghum.

Knowledge of genetic variability is essential in variety selection. Demonstrating this genetic variability for certain morphological traits is the first essential step in the description of genetic resources [23] [24]. The study of the coeffi- 
cients of genotypic variation of progenies from wild parents (CWR) and parents with high transpiration efficiency (HTE) showed high variability among progenies and within the populations. These variations were probably due to differences between the genotypes and especially between the donor parents and the recurrent parent. For the stay green and grain yield traits, the genotypic coefficient of variation of progenies from wild parents (CVG-CWR) showed a greater value than the genotypic coefficient of variation of the progenies derived from the high transpiration efficiency donors (THE), this indicated a significant inter-progeny variability of the progenies derived from crop wild relatives (CWRs). Schreiber et al. [25] reported significant genetic diversity in agronomic traits using wild relatives.

The high significant variability observed in grain yield has also been reported by several previous studies on sorghum [3] [26] [27] [28]. However, the 100 grains weight trait which was used to estimate seed size and grain yield before harvest, according to Deffan et al. [24] showed low variability. Knowledge of genetic variability allows breeding programs to rely on morphological variability [29].

The combined analysis of variance revealed significant effects for the environment, genotypes and genotype-environment interaction. This could confirm a phenotypic diversity within the progeny evaluated and showed different response of the progenies to the environments in terms of chlorophyll content at maturity, stay green, grain yield and flowering date. Previous studies have reported similar results [30]. The significant morphological diversity of the progenies could be attributed on the one hand to the genetic, racial and geographic diversity of the donors and the race of the recurrent parent and on the other hand to backcrossing methods.

The broad sense of heritability in the two environments was high for most of the traits. The higher the broad sense of heritability is, selection will be more effective for the traits [31]. Falconer and MacKay [32] reported that, the values of heritability below $30 \%$ are considered low, they are average between $30 \%-60 \%$ and very high, above $60 \%$. The broad sense of heritability values that were high for most traits could indicate little environmental influence on the traits. In this case, the phenotype is a good predictor of the genotype [33]. The broad sense of heritability is an indicator to predict the response to selection, the more heritable is a trait, the more efficient and rapid the selection is to change the population mean [34] [35]. The broad heritability values of traits in the Cinzana environment were generally higher than those of traits in the Bema environment. This was explained by the fact that heritabilities appear to be stronger in conditions of high water and high fertility levels [36]. These results were similar to those reported by Leiser et al. [37] on the sorghum. The joint estimate of the coefficient of genotypic variation (GCV) and heritability $\left(h^{2}\right)$ provides the best information for the choice of parents for hybrid development in order to obtain the preferred traits [13]. 
The genetic correlations between stay green and lodging and between stay green and chlorophyll content were the highest. Xu et al. [38] reported the relationship between the visual score of stay green and the concentration of leaf chlorophyll in sorghum. Wanous et al. [39] reported that visual assessments of green leaf area and green leaf number correlate strongly with measured values of green leaf area for chlorophyll content under drought stress. Blackmer and Schepers [40] reported a positive correlation of chlorophyll concentration with leaf nitrogen concentration and green leaf coloration in maize. The stay green trait protects the leaf from chlorophyll degradation [41]. The results indicated that visual stay green scores were a reliable indicator of leaf senescence and should be useful for sorghum breeders to assess progeny when breeding for drought tolerance.

The negative correlation between SPADIII and grain yield could be explained by the fact that at maturity there was competition between leaves and grains for chlorophyll. Thus, there was loss of chlorophyll from the leaves to the benefit of grain filling causing leaf senescence in most progenies.

\section{Conclusion}

Seven populations of 669 progenies were developed by introgression (BC1) including five populations from HTE (High Transpiration Efficiency) and two populations from CWR (Crop Wild Relatives). This study highlighted the potential of wild sorghum and high transpiration efficiency landrace to enhance breeding leading to the identification of superior genotypes. It also suggested that wild sorghums are useful as donors for improving yield for farmer-preferred varieties. The characterization showed the existence of a large phenotypic variability for the flowering period, stay green, chlorophyll content, lodging and grain yield within the $669 \mathrm{BC} 1 \mathrm{~F} 5$ progenies. This should enable identification of higher yielding varieties for the drought prone areas in Sahel. The heritability estimates indicated that selection should be effective for grain yield and putative drought tolerance traits. The existence of a correlation between putative drought tolerance traits should be useful to breeders evaluating progenies for drought tolerance. The best selected genotypes were assessed in the farm environment and on-station in 2018 and 2019 using a participatory farmer approach to improve farmers' resilience to climate variability.

\section{Acknowledgements}

The author gratefully thanks the International Crops Research Institute for the Semi-Arid Tropics in Mali (ICRISAT) for providing him this opportunity to carry out a $\mathrm{PhD}$ thesis. The USAID "Feed the Future Innovation Laboratory for Climate Resilient Sorghum" is gratefully acknowledged for the financial support. Our gratefulness to the staff of the Sorghum Breeding Program at the Institut d'Economie Rural (IER) for their support for conducting the trials in this study. We wish to thank the members of Biosciences laboratory of the university 
(Ouagadougou) for their assistance in various aspects of this work.

\section{Conflicts of Interest}

The authors declare no conflicts of interest regarding the publication of this paper.

\section{References}

[1] IFDC (International Fertilizer Development Center) (2006) Global Leaders Launch Effort to Turn around Africa's Failing Agriculture: New Study Reports Three-Quarters of African Farmlands Plagued by Severe Degradation. In: Improvement of Sorghum and Millet, SICNA, Lubbock. http://www.rockefellerfoundation.org/news/press

[2] Dahlberg, J., Berenji, J., Sikora, V. and Latkovic, D. (2012) Assessing Sorghum [Sorghum bicolor (L) Moench] Germplasm for New Traits: Food, Fuels and Unique Uses. Maydica, 56, 85-92.

[3] Djè, Y., Heuertz, M., Ater, M., Lefebvre, C. and Vekemans, X. (2007) Évaluation de la diversité morphologique des variétés traditionnelles de sorgho du Nord-ouest du Maroc. Biotechnologie, Agronomie, Société et Environnement, 11, 39-46.

[4] Agrama, H.A. and Tuinstra, M.R. (2003) La diversité phylogénétique et les relations entre le sorgho adhésions à l'aide SSR et RAPD. African Journal of Biotechnology, 2, 334-340.

[5] Weltzien, E., Rattunde, H.F.W., Van Mourik, T.A. and Ajeigbe, H.A. (2018) Sorghum Cultivation and Improvement in West and Central Africa. In: Achieving Sustainable Cultivation of Sorghum: Sorghum Utilization around the World, Vol. 2, Burleigh Dodds Science Publishing, Cambridge, 217-240.

[6] Bramel-Cox, P.J. and Cox, T.S. (1988) Use of Wild Germplasm in Sorghum Improvement. In: Wilkinson, D., Ed., Proceedings of the 43 rd Annual Corn and Sorghum Industry Research Conference, American Seed Trade Association, Washington DC, 13-25.

[7] Weltzien, E., Christinck, A., Touré, A., Rattunde, F., Diarra, M., Sangaré, A. and Coulibaly, M. (2007) Enhancing Farmers' Access to Sorghum Varieties through Scaling-Up Participatory Plant Breeding in Mali, West Africa. In: Almekinders, C. and Hardon, J., Eds., Bringing Farmers Back into Breeding. Experiences with Participatory Plant Breeding and Challenges for Institutionalization, Agromisa Special 5, Agromisa, Wageningen, 58-69.

[8] Rattunde, W.H.F., Weltzien, E., Diallo, B., Diallo, A.G., Sidibé, M., Toure, A.O., Rathore, A., Das, R.R., Leiser, W.L. and Toure, A. (2013) Yield of Photoperiod-Sensitive Sorghum Hybrids Based on Guinea-Race Germplasm Under Farmers' Field Conditions in Mali. Crop Science, 53, 2454-2461. https://doi.org/10.2135/cropsci2013.03.0182

[9] Bazile, D., Dembélé, S., Soumaré, M. and Dembélé, D. (2008) Utilisation de la diversité variétale du sorgho pour valoriser la diversité des sols au Mali. Cahiers Agricultures, 17, 86-94. https://doi.org/10.1684/agr.2008.0172

[10] FAOSTAT (Food and Agriculture Organization Corporate Statistical Database) (2015) Statistiques des données. United Nations Food and Agriculture Organization, Rome.

[11] Crop Wild Relatives and Climate Change (2013). https://www.cwrdiversity.org/

[12] Talukder, S.K., Prasad, P.V., Todd, T., Mabar, M.A., Poland, J., Bowden, R. and 
Fritz, A. (2015) Effect of Cytoplasmic Diversity on Post Anthesis Heat Tolerance in Wheat. Euphytica, 204, 383-394. https://doi.org/10.1007/s10681-014-1350-7

[13] Burton, G.W. and Devane, E.M. (1953) Estimating Heritability in Tall Fescue (Festuca arundinacea) from Replicated Clonal Material. Agronomy Journal, 45, 478-481. https://doi.org/10.2134/agronj1953.00021962004500100005x

[14] Cullis, B.R., Smith, A.B. and Coombes, N.E. (2006) On the Design of Early Generation Variety Trials with Correlated Data. Journal of Agricultural, Biological, and Environmental Statistics, 11, Article No. 381. https://doi.org/10.1198/108571106X154443

[15] Piepho, H.P. and Möhring, J. (2007) Computing Heritability and Selection Response from Unbalanced Plant Breeding Trials. Genetics, 177, 1881-1888. https://doi.org/10.1534/genetics.107.074229

[16] Henry, R.J. (2014) Sequencing Crop Wild Relatives to Support the Conservation and Utilization of Plant Genetic Resources. Plant Genetic Resources 12, S9-S11. https://doi.org/10.1017/S1479262113000439

[17] Hajjar, R. and Hodgkin, T. (2007) The Use of Wild Relatives in Crop Improvement: A Survey of Developments over the Last 20 Years. Euphytica, 156, 1-13. https://doi.org/10.1007/s10681-007-9363-0

[18] Henry, R.J. and Nevo, E. (2014) Exploring Natural Selection to Guide Breeding for Agriculture. Plant Biotechnology Journal, 12, 655-662.

https://doi.org/10.1111/pbi.12215

[19] Roux, F., Touzet, P., Cuguen, J. and Corre, V. (2006) How to Be Early Flowering an Evolutionary Perspective. Trends in Plant Science, 11, 375-381. https://doi.org/10.1016/j.tplants.2006.06.006

[20] Quinby, J.R. and Karper, R.E. (1954) Inheritance of Height in Sorghum. Agronomy Journal, 46, 211-216. https://doi.org/10.2134/agronj1954.00021962004600050007x

[21] Hanmier, G.L. (2006) Pathways to Prosperity: Breaking the Yield Barrier in Sorghum. Agricultural Science, 19, 16-22.

[22] Gill, B.S., Raupp, W.J. and Friebe, B. (2014) Genomic Perspective on the Dual Threats of Imperiled Native Agroecosystems and Climate Change to World Food Security. Journal of Crop Improvement, 28, 88-98. https://doi.org/10.1080/15427528.2014.865411

[23] Radhouane, L., Aissa, N. and Romdhane, L. (2014) Effets d'un stress hydrique appliqué à différents stades de développement sur l'aspect quantitatif et qualitatif des semences chez un écotype autochtone de sorgho grain (Sorghum bicolor). Journal of Applied Biosciences, 74, 6149-6156. https://doi.org/10.4314/jab.v74i1.6

[24] Deffan, K.P., Akanvou, L., Akanvou, R., Nemlin, G.J. and Kouamé, P.L. (2015) Évaluation morphologique et nutritionnelle de variétés locales et améliorées de maïs (zea mays 1.) produites en Côte d'Ivoire. Afrique SCIENCE, 11, 181-196. http://www.afriquescience.info

[25] Schreiber, M., Himmelbach, A., Borne, A. and Mascher, M. (2019) Genetic Diversity and Relationship between Domesticated Rye and Its Wild Relatives as Revealed through Genotyping-By-Sequencing. Evolutionary Applications, 12, 66-77. https://doi.org/10.1111/eva.12624

[26] Elangovan, M. and Patil, J.V. (2013) Plant Variety Protection and DUS Testing in UK. In: Elangova, M. and Patil, J.V., Eds., Directorate of Sorghum Research, Managing Intellectual Property under PVP and PGR, Hyderabad, 162-166.

[27] Dossou-Aminon, I., Yêyinou, L., Adjatin, L.A., Ewédjè, E.B.K., Dansi, A., Rakshit, 
S., Cissé, N., Patil, J.V., Agbangla, C., Sanni, A., Akoègninou, A. and Akpagana, K. (2015) Genetic Divergence in Northern Benin Sorghum (Sorghum bicolor L. Moench) Landraces as Revealed by Agromorphological Traits and Selection of Candidate Genotypes. Scientific World Journal, 2015, Article ID: 916476, 10 p. https://doi.org/10.1155/2015/916476

[28] Diallo, C., Isaacs, K., Gracen, V., Touré, A., Weltzien, E.R., Danquah, E.Y., Sidib, M.é, Dzidzienyo, D.K., Rattunde, F., Nébié, B., Sylla, A. and Tongoona, P.B. (2018) Learning from Farmers to Improve Sorghum Breeding Objectives and Adoption in Mali. Journal of Crop Improvement, 32, 829-846. https://doi.org/10.1080/15427528.2018.1531800

[29] Oulmi, A., Nadjim, S., Manel, S., Laala, Z., Rabti, A. and Benmahammed, A. (2016) Variabilité génétique, héritabilité et corrélationsentre les caractères phéno-morphophysiologiques et agronomiques des populations $\mathrm{F}$ de blé dur (Triticum durum Desf.). International Journal of Innovation and Applied Studies, 17, 1275-1285.

[30] Ndiaye, M., Adam, M., Muller, B., Guisse, A. and Cisse, N. (2018) Performances agronomiques et stabilité phénotypique de génotypes de Sorgho (Sorghum bicolor L. Moench) au Sénégal: Une étude des interactions génotypes-environnement. Journal of Applied Biosciences, 125, 12617-12629.

https://doi.org/10.4314/jab.v125i1.10

[31] Standfield, P.R. (1975) The Effect of Zinc Ions on the Gating of the Delayed Potassium Conductance of Frog Sartorius Muscle. The Journal of Physiology, 251, 711-735. https://doi.org/10.1113/jphysiol.1975.sp011118

[32] Falconer, D.S. and Mackey, T.F.C. (1996) Introduction to Quantitative Genetics. 4th Edition, Longmans Green, Harlow.

[33] Visscher, P.M., Hill, W.G. and Wray, N.R. (2008) Heritability in the Genomics Era-Concepts and Misconceptions. Nature Reviews Genetics, 9, 255-266. https://doi.org/10.1038/nrg2322

[34] Benmahammed, A. (1995) Associations et héritabilités de quelques caractères à variation continue chez l'orge (Hordeum vulgare L.). Thèse de Magister, INA-El Harrach, Alger, $80 \mathrm{p}$.

[35] Nouri, L. (2011) Identification de marqueurs physiologiques de la tolérance à la sécheresse chez le tournesol. Thèse de Doctorat de Science, spécialité, Biologie et Physiologie végétales, option, Génétique et Amélioration des plantes, Université Constantine, Constantine, $131 \mathrm{p}$.

[36] Brancourt-hulmel, M., Doussinault, G., Lecomte, C., Berard, P., Buanec, B. and Trottet, M. (2003) Genetic Improvement of Agronomic Traits of Winter Wheat Cultivars Released in France from 1946 to 1992. Crop Science, 43, 37-45. https://doi.org/10.2135/cropsci2003.3700

[37] Leiser, W.L., Rattunde, H.F., Piepho, H.P. and Parzies, H.K. (2012) Getting the Most Out of Sorghum Low-Input Field Trials in West Africa Using Spatial Adjustment. Journal of Agronomy and Crop Science, 198, 349-359.

https://doi.org/10.1111/j.1439-037X.2012.00529.x

[38] Xu, W., Subudhi, R.K., Crasta, O.R., Rosenow, D.T., Mullet, J.E. and Nguyen, H.T. (2000) Molecular Mapping QTLs Conferring Stay-Green in Grain Sorghum (Sorghum bicolor L. Moench). Genome, 43, 461-469.

[39] Wanous, M.K., Miller, F.R. and Rosenow, D.T. (1991) Evaluation of Visual Rating Scales for Green Leaf Retention in Sorghum. Crop Science, 31, 1691-1694. https://doi.org/10.2135/cropsci1991.0011183X003100060063x 
[40] Blackmer, T.M. and Schepers, J.S (1995) Use of Chlorophyll Meter to Monitor N Status and Schedule Fertigation of Corn. Journal of Production Agriculture, 8, 56-60. https://doi.org/10.2134/jpa1995.0056

[41] Walulu, R.S., Rosenow, D.T., Wester, D.B. and Nguyen, H.T. (1994) Inheritance of the Stay Green Trait in Sorghum. Crop Science, 34, 970-972.

https://doi.org/10.2135/cropsci1994.0011183X003400040026x 